\title{
The effect of technology on the development and income of goat business in Kulon Progo, Yogyakarta
}

\author{
Christina Astri Wirasti ${ }^{*}$, Gunawan ${ }^{1}$, Siti Andarwati ${ }^{2}$, and I. Gede Suparta Budisatria ${ }^{2}$ \\ ${ }^{1}$ Yogyakarta Assessment Institute for Agricultural Technology. Maguwoharjo 22 $2^{\text {rd }}$, Karangsari, \\ Wedomartani, Ngemplak, Sleman, 55584 Yogyakarta, Indonesia. \\ ${ }^{2}$ Faculty of Animal Science, Universitas Gadjah Mada. Fauna $3^{\text {rd }}$, Kampus UGM Bulaksumur, 55281 \\ Yogyakarta, Indonesia.
}

\begin{abstract}
The aim of this study was to determine the effect of introduction technology on the development of goats and income of goat business. This study was conducted at 4 farmer groups in Kulon Progo regency, Yogyakarta. The study has been done on 83 farmers in model A and 28 farmers in model B. Model A is a goat farming model with innovation, while model B without innovation. Innovation in farmers model A include the use of stage cages, mating calendars and optimization of goat feed by utilizing cocoa biomass. The variables observed were goat productivity for 9 months (April to December, 2015). Independent t-test was done to analyze the productivity of goats between models A and B. The results showed that the average number of goats for 9 months on model A increased from 4.2 to 5.0 heads, whereas in model B increased from 3.4 to 3.8 heads. The birth of a kid for 9 months on model A was $1.9 \pm 0.9$ heads higher than model B of $1.2 \pm 0.3$ heads. Income on farmer model A (IDR 3.28 million/year) higher than farmer model B (IDR 0.97 million/year). The study implied that introduction technology should be increased the goat productivity and income of goat business.
\end{abstract}

\section{Introduction}

Goat is one of the ruminants that easily adapt to the environment and are efficient on converting low-quality feed to meat. Goat meat is popular by the community and has a distinctive taste when compared with other meat. Goat farming is generally a smallholder farmers activity in the village, so that productivity and income from goat farming is still low. However, goats raised by smallholder farmers can reduce poverty, especially in poor and developing countries [1].

Goat farming in cocoa plantations can utilize cocoa biomass to feed goats, while goat manure is processed into fertilizer for cocoa plants, especially to increase cocoa production and reduce the use of chemical fertilizers [2]. Cocoa plantations have an opportunity to develop goats, one of the reasons is the availability of abundant feeding potential of cocoa biomass. The cocoa farmer's income is able to increase through the use of cocoa biomass.

* Corresponding author: mahastrie@gmail.com 
Improving the quality of goat feed using cocoa biomass can improve goat productivity and farmer income [3].

Potential cocoa biomass as animal feed is cocoa pod husk, cocoa leaf, cocoa shell bean and cocoa bean cake. Gunawan, et al., [4] found that $60-75 \%$ of cocoa pod husk is wasted at harvest time and it's not optimally utilized as goat feed. In Nigeria, Ghana and India, the cocoa pod husk is generally used as feed $[5,6,7]$. There have been many studies on the use of cocoa pods as feed $[8,9,10]$, even silage is made from cocoa pods $[11,12,13]$ and efforts to improve feed quality using cocoa pods $[14,15]$. However, research on the use of cocoa leaves as goat feed is still scarce and many farmers have not used cocoa leaves to feed goats either in fresh form or silage.

Improvement productivity of goats can be done, among others, through the application of mating calendars [16]. The mating calendars contain schedules for when goats are born, when mated again, when kids are weaned and when goats need to be given additional feed during pregnancy or after birth. According to Gunawan et al., [16] the birth of a kid to a farmer who uses innovation is higher than a farmer without innovation, especially by the use of mating calendars. The use stage cages make goats live more comfortably and manure can be processed into organic fertilizer to be sold as additional income for farmers.

Based on the above description, it is necessary to conduct a study about the effort to increase goat productivity in Kulon Progo farmer's through technological innovation. The aim of this study is to determine the effect of technology innovation to improve goat productivity and to increase the goat farming income. Innovations in goat farming include the use of stage cages, mating calendars and optimization of goat feed by utilizing cocoa biomass (fresh cocoa pod husk, cocoa leaves and cocoa leaf silage).

\section{Materials and methods}

\subsection{Model and farmers involved}

This study was conducted at 4 farmer groups, located in Banjarharjo and Banjaroya Villages, Kalibawang Sub-District, Kulon Progo Regency, Yogyakarta special region province, Indonesia. The number of farmers involved in this study were 111 people which divided into 2 models namely model A ( 83 people) and B ( 28 people). Farmers are selected by purposive random sampling $[17,18]$. Model $\mathrm{A}$ is farmers who apply goat farming using innovation, while the technology used in farmers model B is the farmers' experience, without innovation. Goats kept by most farmers are Bligon goat for meat. The explanations of models A and B are listed in Table 1. 
Table 1. Description of the model and innovation in models A and B

\begin{tabular}{|l|l|l|}
\hline Description & \multicolumn{1}{|c|}{ Model A } & \multicolumn{1}{c|}{ Model B } \\
\hline $\begin{array}{l}\text { Model } \\
\text { explanation }\end{array}$ & $\begin{array}{l}\text { Goat farming model with } \\
\text { innovation }\end{array}$ & $\begin{array}{l}\text { Goat farming model in the way of } \\
\text { farmers, without innovation. }\end{array}$ \\
\hline Innovation & $\begin{array}{l}\text { Goat farming technology uses } \\
\text { stage cages, mating calendars } \\
\text { and optimization of goat feed } \\
\text { by utilizing fresh cocoa pod } \\
\text { husk, cocoa leaves and cocoa } \\
\text { leaf silage. }\end{array}$ & $\begin{array}{l}\text { Goat farming technology uses ground } \\
\text { floor cages, mating arrangement of goats } \\
\text { without calendars and goat feed mostly } \\
\text { using grass, without harnessing cocoa pod } \\
\text { husk and cocoa leaves. }\end{array}$ \\
\hline
\end{tabular}

\section{2,2 Farming income analysis}

The income earned by farmers from goat farming in each model was analyzed using farm income analysis [19]. The farm income was derived from the total revenue minus the total cost of the goat farming. This revenue analysis was conducted to determine the magnitude of the increase in revenues caused by innovation.

\subsection{Statistical analysis}

The variables observed in models $\mathrm{A}$ and $\mathrm{B}$ are goat productivity. Observation of goat productivity was done for 9 months (April to December, 2015) using farm record keeping. The productivity of goats between models A and B was analyzed using independent t-test [20]. If $t$ count $>t$ table it will indicate that between models were significantly different (Ho was rejected) and if $t$ count $<\mathrm{t}$ table it was not significantly different (Ho was accepted).

\section{Results and discussion}

\subsection{Goat productivity}

The number of goats in A model farmer for 9 months showed an increase $(0.8 \pm 0.5$ head) due to birth of goat ( $1.9 \pm 0.9$ heads) from the average number of does of 2.1 head, whereas in model $\mathrm{B}$ the number of goats was only increase $(0.4 \pm 0.3$ head $)$, due to the birth of goat was low (1.2 \pm 0.3 heads) from the average number of does of 1.9 head (Table 2$)$. The average number of goats on farmers of model A initially (April, 2015) was 4.2 head after 9 months (December, 2015) to 5.0 head, whereas in farmers model B the average number of goats at the beginning and end was the early same, namely 3.4-3.8 head.

Table 2. Productivity of goats raised by the farmers in models A dan B for 9 months

\begin{tabular}{|l|c|c|}
\hline Description & Model A & Model B \\
\hline & - & $---.^{-}-.^{\mathrm{a}}$ \\
\hline Birth of goats & $1.9 \pm 0.9^{\mathrm{a}}$ & $1.2 \pm 0.3^{\mathrm{b}}$ \\
\hline Mortality of goats & $0.5 \pm 0.3^{\mathrm{a}}$ & $0.5 \pm 0.5^{\mathrm{a}}$ \\
\hline Purchasing goats & $0.5 \pm 0.3^{\mathrm{a}}$ & $0.3 \pm 0.2^{\mathrm{a}}$ \\
\hline Selling goats & $1.2 \pm 0.6^{\mathrm{a}}$ & $0.6 \pm 0.2^{\mathrm{b}}$ \\
\hline Addition & $0.8 \pm 0.5^{\mathrm{a}}$ & $0.4 \pm 0.3^{\mathrm{b}}$ \\
\hline
\end{tabular}

${ }^{a b}$ Different superscripts denote significant differences between means within a row $(\mathrm{p} \leq 0.05)$

The results of this study are close to ideal, the productivity of each doe on a farmer of model $\mathrm{A}$ is $0.8 \mathrm{head} / 9$ months, ideally at least $1.0 \mathrm{head} / 8$ months. According to Murdjito et al., [21] and Sutama [22] if the does are mated at 1 to 2 months after the birth and weaning 
of the young goats at 3 to 4 months, the kidding interval was 7 to 8 months, so that each of the doe can deliver the kids 3 times in 2 years. The productivity of the doe can be optimized by the use of mating calendars, because it's can remind farmers to mate their doe so that the kidding intervals are shorter and more productive [16].

Optimizing the provision of goat feed at farmers in model $\mathrm{A}$ is done by utilizing cocoa leaves resulting from pruning of cocoa tree and cocoa pod husk result from harvest. This is not so in farmers model B. The use of fresh cocoa pod husk as goat forage average 103 $\mathrm{g} /$ head/day approached the previous research result of $110 \mathrm{~g} / \mathrm{head} /$ day, the use of fresh cocoa leaves of $105 \mathrm{~g} / \mathrm{head} /$ day also approached the previous research result of $130 \mathrm{~g} / \mathrm{head} /$ day [23]. Cocoa leaf silage has been used as goat forage on farmers in model A as much as 28 $\mathrm{g} /$ head/day. Utilization of cocoa biomass as goat forage on farmers in model A is still limited, $236 \mathrm{~g} / \mathrm{head} /$ day, because pruning of cocoa tree branches is not routinely done. Optimization of feed provision has an effect on optimizing goat reproduction function.

\subsection{Goat farming income}

Income from goat farming of farmer in model A (IDR 3.28 million) is increased than model B (IDR 0.97 million), partly because the goat sold and goat added value in farmer model A is higher than model B (Table 3). According to Esong, et al. [9] the increase of goat farming income gained from more profitable sale of goats. The result of goat sales is mainly obtained from the sale of goat which has been prepared by farmers for sale on the event of Eid-al Adha. Eid-al Adha has a significant effect on the marketing of small ruminants, the price of goats sold during Eid-al Adha increased compared to the normal situation thereby increasing farmers' income [24].

Table 3. Goat farming income per year in farmers models A and B

\begin{tabular}{|l|r|r|r|r|}
\hline \multirow{2}{*}{ Description } & \multicolumn{2}{|c|}{ Model A } & \multicolumn{2}{c|}{ Model B } \\
\cline { 2 - 5 } & Volume & Value (IDR) & \multicolumn{1}{c|}{ Volume } & \multicolumn{1}{c|}{ Value (IDR) } \\
\hline Revenue & & & & \\
\hline 1. Goat sales & $1.2 \mathrm{head}$ & $3,110,000$ & $0.6 \mathrm{head}$ & 876,000 \\
\hline 2. Addition of goats & $0.8 \mathrm{head}$ & $1,062,500$ & $0.4 \mathrm{head}$ & 337,500 \\
\hline 3. Selling manure & $116 \mathrm{~kg}$ & 116,250 & 0 & 0 \\
\hline Total revenue & & $4,288,750$ & & $1,213,500$ \\
\hline Cost & & & & 219,000 \\
\hline 1. Purchase of goat & 0.5 ekor & 697,500 & $0.3 \mathrm{head}$ & 25,000 \\
\hline $\begin{array}{l}\text { 2. The value of the cage } \\
\text { shrinkage }\end{array}$ & 1 year & 250,000 & 1 year & 0 \\
\hline 3. Medicines & 1 year & 40,000 & 0 & 0 \\
\hline 4. Feed (rice bran for silage) & $2.4 \mathrm{~kg}$ & 7,325 & 0 & 0 \\
\hline 5. Mineral block & $1.5 \mathrm{~kg}$ & 14,875 & & 244,000 \\
\hline Total costs & & $1,009,700$ & & 969,500 \\
\hline Income & & $3,279,050$ & & 0 \\
\hline
\end{tabular}

Note: goat selling price: IDR 1,500,000-2,600,000 per head, the value of goat addition: IDR $850,000-$ $1,350,000$ per head, goat purchase price: IDR 730,000-1,400,000 per head, the value of shrinkage cage: IDR 2,500,000/10 years (model A) and IDR 250,000/10 years (model B), medicines (model A): IDR 40,000/year, rice bran price: IDR 3,050/kg, Mineral block price: IDR $10,000 / \mathrm{kg}$, goat manure price: IDR $1,000 / \mathrm{kg}$.

In some results of studies show that the number of goats maintained by the farmers has an influence on the farming income obtained from goat raising $[25,26]$. In this study, the number of does in model A and B did not different, namely 2.1 head (model A) and 1.9 head (model B). The results of this study indicate that the income of goat farming per year increased from 
IDR 0.97 million to IDR 3.28 million through innovation including the use of stage cage, mating calendars and optimization of feed by utilizing cocoa leaves and pod husk.

\section{Conclusion}

Introduction technology in goat farming has a significant effect on goat productivity and farmer income. The birth of a kid to a farmer who uses innovation is higher than a farmer without innovation, by the use of stage cages, mating calendars and optimization of goat feed by utilizing fresh cocoa pod husk, cocoa leaves and cocoa leaf silage. The income of goat farming on innovative farmers is also higher than that of farmers without innovation, mainly from the increase of goat addition and higher goat sales.

\section{References}

1. Pica-Ciamarra, U., L. Tasciotti, J. Otte, A. Zezza, Dev. Policy Rev. 33,1, 61-81. (2015)

2. Gunawan, C. Talib, Wartazoa. 24, 4, 163-172 (2016)

3. Gunawan, I.G.S. Budisatria, Asian J. Anim. Sci. 10, 6, 273-279 (2016)

4. Gunawan, Sukar, W I Werdhany, S.W. Budiarti, S. Widyayanti, T. Siswanto, Sutarno, A. Marthon, N. Siswanto, R.U. Hatmi, Assessment of development model of cocoa-goat integration for increasing goat productivity and farmers income in Kulon Progo Regency, Yogyakarta Special Region Province, Indonesia. (Yogyakarta Assessment Institute for Agricultural Technology, 2012)

5. Duku, M.H., Sai Gu, E.B. Hagan, Renew. and Sustain. Energy Rev. 15, 404-415 (2011)

6. Simonyan, K.J, O. Fasina, Afr. J. Agric. Res. 8, 40, 4975-4989 (2013)

7. Sadasivuni, S., R. Bhat, C. Pallem, Environ. Technol. Rev. 4, 1, 91-102 (2015)

8. Ali, H.M., G. Alam, J. A. Syamsu, Salengke, M.A. Asja, J. Advanced Agric. Technol. 1, 1, 5-9 (2014)

9. Esong R.N., K.A. Etchu, P.H. Bayemi, P.V. Tan, Trop. Anim. Health Prod. 47, 7, 1411 $1416(2015)$

10. Puastuti, W., Y. Widiawati, E. Wina, Indonesian J. Anim. and Veterinary Sci. 20, 1, 31 $40(2015)$

11. Serli, A., A. Zubair, D. Rohmadi, J. Agrisistem.7, 79-86 (2011)

12. Suparjo, S., K.G. Wiryawan, E.B. Laconi, D. Mangunwidjaja, Media Peternak. 34, 1, 35-41 (2011)

13. Wulandari, S., A. Agus, M.N. Cahyanto, R. Utomo, J. Indonesian Trop. Anim. Agric. 39, 3, 167-174 (2014)

14. Laconi, E.B., A. Jayanegara, Asian-Australian J. Anim. Sci. 28, 3, 343-350 (2015)

15. Zakariah, M.A., R. Utomo, Z. Bachruddin, Bul. Peternak. 40, 2, 124-132 (2016)

16. Gunawan, W. I. Werdhany, I.G.S. Budisatria, The effect of innovation on increasing productivity and goat farming income in cocoa-goat integration system, in Proceedings of the 7th International congress on Tropical Animal Production. 12-14 September 2017, Yogyakarta, Indonesia, 571-575 (2017)

17. Taherdoost, H., IJARM 5, 2, 18-27 (2016)

18. Triyono, Sampling Technique Upgrading of Research Data Analysis for Lecturers of Private (Kalimantan: Universities XI, 2019)

19. Shinta, A, Farming Science (Brawijaya University Press, Malang, Indonesia, 2011)

20. Cohort, CoSTAT Version 6.400 (Copyright 1998-2008, Cohort Software. 798, Lighthouse Ave, Montere, CA. 93940, USA, 2008)

21. Murdjito, G., I.G.S. Budisatria, Panjono, N. Ngadiono, E. Baliarti, Bul. Peternak. 32, 2, 86-95 (2011) 
22. Sutama, I.K, Pengemb. Inov. Pertan. 4, 3, 231-246 (2011)

23. Gunawan, W.I. Werdhany, Sukar, S.W. Budiarti, T. Siswanto, S. Widyayanti, Sutarno, E.P. Astuti, Development model of cocoa-goat integration in Kulon Progo Regency, Yogyakarta Special Region Province, Indonesia (Yogyakarta Assessment Institute for Agricultural Technology, 2013)

24. Welerubun, I.N., T. Ekowati, A. Setiadi, J. Agromedia 34, 2, 54-64 (2016)

25. Yusuf, R., Income analysis of raising goats on different scales of ownership in Palipi Soreang village, Banggae Sub-district, Majene Residence [Skripsi] (Faculty of Animal Science, Hasanudin University, Makassar, Indonesia, 2017)

26. Budisatria, I.G.S., C.H.A.M. Eilers, H.M.J. Udo, E. Baliarti, A.J. van der Zijpp, Small Rumin. Res. 88, 16-22 (2010) 